\title{
Phonological Short-Term and Working Memory in 5- and 6-Year-Old Children with Speech Sound Disorders
}

\author{
Ki-Eun Lee ${ }^{\mathrm{a}, \mathrm{b}}$, Ji-Wan Ha ${ }^{\mathrm{a}, \mathrm{c}}$ \\ ${ }^{a}$ Department of Speech and Language Pathology, Graduate School of Rehabilitation Science, Daegu University, Gyeongsan, Korea \\ ${ }^{b}$ Good Mind Language Development Center, Busan, Korea \\ 'Department of Speech Pathology, Daegu University, Gyeongsan, Korea
}

Correspondence: Ji-Wan $\mathrm{Ha}, \mathrm{PhD}$ Department of Speech Pathology, Daegu University, 201 Daegudae-ro, Jillyang-eup, Gyeongsan 38453, Korea

Tel: $+82-53-850-4327$

Fax: +82-53-850-4329

E-mail: jw-ha@daegu.ac.kr

Received: July 20, 2018

Revised: August 9, 2018

Accepted: August 9, 2018

This work was supported by the Daegu University Research Grant 2016 (No. 20160416).
Objectives: The purpose of this study was to compare phonological short-term and working memory processes in children with speech sound disorders (SSD) and their typically developing (TD) peers. Additionally, the study aimed to explore the relationship among two memory functions, articulation and vocabulary abilities. Methods: Forty 5- and 6-yearold children enrolled: 20 children with SSD and 20 TD children. Children participated in three memory tasks, digit span forward, digit span backward, and nonword repetition. Results: In all tasks, significant differences were observed between SSD and TD groups, and between the 5- and 6-year-old age groups. According to task type and number of syllables, the performances of SSD and TD children were different in experimental tasks. Moreover, when the age was included as an independent variable of digit span tasks, another aspect of the differences between the groups was observed. In addition, the task performances were not correlated with the percentage of consonants correct, but instead showed a significant correlation with the receptive and expressive vocabulary in SSD and TD children. Conclusion: Phonological memory, especially phonological working memory, was weaker in SSD children in comparison to TD children. These results suggest that profound difficulties in phonological working memory are linked to persistent speech sound disorders. The theoretical and clinical implications are discussed about phonological memory and vocabulary acquisition in SSD children.

Keywords: Speech sound disorder, Phonological short-term memory, Phonological working memory, Digit span, Nonword repetition
원인 모르는 말소리장애(speech sound disorder with unknown origin)는 근본적인 원인이 아직 명확하게 밝혀지지 않은 모든 말소 리장애에 대해 광범위하게 사용되는 용어이다. 결함을 초래한 일차 적 원인을 밝히는 것은 매우 요원한 일인 만큼, 이에 대한 대안책으 로 말소리장애와 관련 있는 기저 요인들(underlying factors)에 관 한 연구가 활발히 진행되고 있다. 그 가운데 말소리산출의 가장 기 저 단계라고 할 수 있는 음운표상에 관한 연구들도 다수 찾아볼 수 있다. 음운표상의 초기 형성능력 결함(Bae, $\mathrm{Ha}, \mathrm{Koo}, \mathrm{Hwang}$, \& Pyun, 2016), 저장되어 있는 음운표상의 비명료함(Kim \& Ha, 2014; Sutherland \& Gillon, 2005, 2007), 음운표상 인식능력의 결함(Jung,
Choi, \& Ha, 2015), 음운표상 부호화능력의 결함(Kim \& Ha, 2014) 등이 그것이다. 그런데 이러한 음운표상을 성공적으로 형성하고, 유지하고, 인식하고, 부호화하기 위해서는 공통적으로 요구되는 능 력이 있는데, 그것이 바로 음운기억이다. 즉, 일련의 음운정보를, 그 것이 새로운 정보이든 장기기억 속에 이미 저장되어 있는 정보이든 간에, 일정 시간 동안 보유할 수 있는 능력이 기본적으로 있어야 이 모든 활동이 가능해진다(Afshar, Ghorbani, Rashedi, Jalilevand, \& Kamali, 2017).

음운기억은 음운단기기억과 음운작업기억으로 나눌 수 있다. 이 둘은 음운정보의 일시적 저장소라는 측면에서 동일하지만, 적극적 
처리(processing)가 동반되었는지에 따라 그 역할이 구분된다(Archibald \& Gathercole, 2006). 음운단기기억은 정보를 단지 수동적 으로 보유하는 저장소의 역할만을 하기 때문에 그 정보는 금방 사 라질 수 밖에 없다. 반면 음운작업기억은 적극적인 시연과정(subvocal rehearsal)을 통해 사라지는 음운정보를 반복적으로 되뇜으 로써 보다 오랫동안 정보를 유지할 수 있고, 결과적으로 해당 정보 를 장기기억 속에 표상으로 저장하는 데에 기여하는 바가 크다. Baddeley는 그의 작업기억모델에서 음운루프를 통해 이와 같은 음운 단기기억과 시연과정, 그리고 음운작업기억의 관계를 체계화하였 다(Baddeley, 2003; Baddeley \& Hitch, 1974). Baddeley의 작업기억 은 단기기억을 바탕으로 이루어지지만 이와는 분명 구분되는 개념 으로, 작업기억모델의 또 다른 하위요소인 중앙집행기(central executive)의 통제를 받는, 처리와 조작활동을 포함한 인지적 기제이다.

그럼에도 불구하고 단기기억과 작업기억의 개념이 모호하게 사 용된 경우를 찾아볼 수 있다. 음운기억을 측정하는 대표적인 과제 로 숫자폭(digit span) 검사를 들 수 있는데, 제시한 여러 개의 숫자 자극을 앞에서부터 뒤로 순서대로 따라하게 하느냐, 아니면 뒤에서 부터 앞으로 거꾸로 따라하게 하느냐에 따라, 전자는 음운단기기억 을, 후자는 음운작업기억을 측정하는 것으로 알려져 있다(Sung, 2011). 즉, 거꾸로 따라하기는 일련의 숫자자극의 정보를 유지하면 서 그것을 역순으로 조작하여 반응해야 하므로, 처리능력이 보다 요구된다. 그러나 숫자폭 검사의 전통적인 채점방법은 두 과제 수 행력을 합산하여 총점으로 결과를 제시하기 때문에, 단기기억과 작업기억과제의 구분이 의미가 없어졌다는 제한점이 있었다. 또한 과제의 난이도가 높아질수록 그것이 단기기억을 측정하는 것인지, 작업기억을 측정하는 것인지 그 경계가 모호한 경우도 있다. 음운 단기기억 측정을 위한 과제에서 자극의 길이가 길어질수록, 과제의 성공적인 수행을 위해서는 실질적으로 단기기억 이상이 요구되기 도 한다. 예를 들어 비단어 따라말하기는 분명 숫자 바로 따라하기 와 그 성격이 유사하다. 그러나자극이 길어질수록, 즉 의미 없는 말 소리들의 긴 나열을 정확하게 기억해내는 능력이 더욱 요구될수록, 자극을 단순히 수동적으로 따라말하는 것이 아니라 수행을 성공하 기 위해 나름의 전략을 사용하게 된다. '전략'이 추가됨으로써 과제 수행과정은 수동적인 보유를 넘어 적극적인 조작활동으로 간주될 수 있고, 따라서 이는 단기기억보다는 작업기억에 가까워진다. 이와 같은 이유 때문인지 비단어 따라말하기 과제는 연구자에 따라 때 로는 단기기억 과제로(Lee, Ha, Koo, Hwang, \& Pyun, 2016; Newbury, Bishop, \& Monaco, 2005; Tkach et al., 2011), 때로는 작업기 억 과제(Farquharson, Hogan, \& Bernthal, 2018)로 명명되고 있다.

앞에서 언급하였듯이 말소리장애와 관련하여 음운기억의 결함
이 여러 연구들에서 보고되었다. 그러나 그것이 음운단기기억과 음 운작업기억 중 어떤 것과 관련된 것인지를 명확하게 밝힌 연구는 찾아보기 어렵다. 적극적인 중재에도 불구하고 학령기 이후 잔존오 류(residual error)를 계속 보이는 지속적 말소리장애(persistent speech sound disorder)의 경우, 오류를 지속시키는 요인으로 음운 단기기억이 아닌 음운작업기억의 결함이 언급된 바 있다(Farquharson et al., 2018). 이러한 연구를 고려할 때, 말소리장애와 음운 단기기억, 그리고 음운작업기억의 관계를 좀 더 명확히 해줄 필요 가 있다.

따라서 본 연구에서는 말소리장애 아동을 대상으로 음운단기기 억과 음운작업기억 능력을 비교하고자 하였다. 음운단기기억 과제 로 숫자 바로 따라하기를, 음운작업기억 과제로 숫자 거꾸로 따라 하기를 사용하는 것에 대부분의 연구자들이 별다른 이견이 없는 만큼, 본 연구에서도 두 과제의 수행결과를 분석하여 두 기억능력 을 비교할 것이다. 그러나 비단어 따라말하기의 경우 그것이 단기기 억과 작업기억 중 어디에 해당하는지에 대해 연구자마다 다소 상 이한 견해를 가지고 있는 듯 하다. 때문에 자극어 길이를 다양하게 하여 각 비단어 따라말하기 수행력을 분석하고 그것을 숫자 바로 및 거꾸로 따라하기 결과와 비교 고찰함으로써, 과제의 성격과 그 로 인한 말소리장애 아동의 특성을 파악하고자 하였다.

더 나아가 지속적 말소리장애와 음운작업기억의 관계를 좀 더 명확하게 밝힐 필요가 있다. 지속적 말소리장애를 예측할 수 있는 결정적 연령(critical age)으로 Bishop과 Adams (1990)은 5세 6개월 을, Shriberg, Austin, Lewis, McSweeny와 Wilson (1997)은 6세 이 후를 제시한 바 있다. 즉 적극적인 중재를 받을 경우 말소리장애는 5 세 경에 대부분 해결되기 때문에, 5 세 6개월 혹은 6 세 이후에도 여 전히 말소리 문제를 보인다면 그 아동은 잔존오류를 계속 보이는 지속적 말소리장애로 발전할 가능성이 크다. 따라서 5 세와 6 세 간 연령 경계는 말소리장애에서 상당히 의미 있는 기준인 듯하다. 그 럼에도 불구하고 연령을 구분하지 않은 채 다양한 연령대의 아동 들을 학령전기 말소리장애의 동일 집단으로 묶어 연구하는 경우가 대부분으로, 5 세와 6 세 집단을 구분하여 음운단기기억과 음운작 업기억 수행력을 비교해볼 필요가 있다. 또한 대표적인 말, 언어 특 성인 자음정확도, 수용어휘량 및 표현어휘량과 음운단기기억, 음 운작업기억 간 관계를 밝혀준다면, 말소리장애 아동을 대상으로 음운기억 연구를 진행하는 본 논문의 의의가 보다 확고해질 것이다. 이상과 같은 연구의 필요성에 근거하여, 본 논문에서는 다음과 같은 연구질문들을 다루고자 하였다. 첫째, 5 세와 6 세의 말소리장 애 아동과 일반아동 간 과제유형(바로 따라하기, 거꾸로 따라하기) 에 따른 숫자 따라하기 수행력에 차이가 있는가? 둘째, 5 세와 6세의 
말소리장애 아동과 일반아동 간 음절 수(3음절, 4 음절, 5 음절)에 따른 비단어 따라말하기 수행력에 차이가 있는가? 셋째, 말소리장 애 집단과 일반 집단에서 각 과제의 수행력과 자음정확도, 수용어 휘량, 표현어휘량 간 상관관계는 어떠한가?

\section{연구방법}

\section{연구대상}

본 연구의 대상자는 5, 6세 말소리장애 아동 20명과 일반아동 20 명이었고, 각 집단 내에서 연령에 따라 5 세 집단과 6 세 집단으로 다 시 10 명씩 분류되었다. 말소리장애 아동은 전문 언어재활사에 의해 다른 장애를 동반하지 않은 순수 말소리장애(pure speech sound disorder)로 진단 받은 아동들로, 모두 말소리장애 치료경험이 있었 다. 연구자는 다음과 같은 기준을 적용하여 각 대상자가 순수 말소 리장애에 해당하는지 한 번 더 확인하는 절차를 거쳤다. 순수 말소 리장애의 판단 기준은 (1) 부모의 의해 신체적, 신경학적, 감각적, 언 어적 및 인지적 영역에서 어떠한 결함도 없는 것으로 보고되었을 것, (2) 수용·표현어휘력검사(Receptive \& Expressive Vocabulary Test, REVT; Kim, Hong, Kim, Jang, \& Lee, 2009)의 수용어휘 및 표현어휘능력이 -1 SD 이상 범위에 속할 것, (3) 우리말 조음-음운 평가(Urimal Test of Articulation and Phonology, U-TAP; Kim \& Shin, 2004)의 단어 수준 자음정확도가 -2 SD 이하에 속할 것, (4) 조음기관의 구조적 결함이 관찰되지 않을 것이었다. 이후 연구대상 으로 선정된 말소리장애 아동과 생활월령이 \pm 2 개월 이내에 해당 하는 일반아동을 모집하였다. 일반아동의 선정기준은 (1) 부모의 보고에 의해 신체적, 신경학적, 감각적, 언어적, 인지적 문제가 없는 것으로 보고되었을 것, (2) 수용-표현어휘력검사의 수용어휘 및 표 현어휘능력이 $-1 \mathrm{SD}$ 이상 범위에 속할 것, (3) 우리말 조음·음운평
가의 단어 수준 자음정확도가 -1 SD 이상 범위에 속할 것이었다. 이와 같은 대상아동들의 기본정보는 Table 1 에 제시하였다. 말소리 장애 집단과 일반 집단 간 생활월령, 수용어휘력 및 표현어휘력에 는 유의한 차이가 없었으나 $(p>.05)$, 말소리장애 집단은 일반 집단 보다 자음정확도가 유의하게 떨어졌다 $(p<.001)$. 그리고 두 집단 모 두에서 6 세는 5 세 보다 자음정확도, 수용어휘력 및 표현어휘력이 유의하게 높았다 $(p<.001)$.

\section{실험 과제}

\section{숫자 바로 따라하기 및 숫자 거꾸로 따라하기 과제}

본 연구의 실험 과제로 한국 웩슬러아동지능검사(Korean-Wechsler Intelligence Scale for Children-IV, K-WISC-IV; Kwak, Oh, \& Kim, 2011)의 소검사 가운데 숫자 바로 따라하기와 숫자 거꾸로 따라하 기 검사항목을 사용하였다. 숫자 바로 따라하기는 검사자가 일련의 숫자를 불러주면 그것을 동일한 순서로 그대로 따라하는 과제이 고, 숫자 거꾸로 따라하기는 검사자가 불러준 숫자를 뒤에서부터 앞으로, 즉 반대 방향으로 따라하는 과제이다. 2 개의 숫자부터 9 개 의 숫자까지, 모두 8 단계로 이루어져 있다. 각 단계는 2 항목씩 구성 되어 전체 항목은 총 16 개이다. 각 시행은 반복하지 않고 한 차례의 기회만 주어지며, 숫자 자극 전체에 대해 정확하게 따라하면 1점, 그 이외에는 모두 0 점으로 처리된다. 따라서 모든 항목을 정반응한 경우 숫자 바로 따라하기 및 거꾸로 따라하기에서 각각 16 점씩을 받게 된다.

\section{비단어 따라말하기 과제}

본 연구팀이 제작한 비단어 따라말하기 과제(Lee et al., 2016)에 서 $3,4,5$ 음절 항목 중 일부를 사용하였다. 비단어 항목은 그 자체 로는 의미가 없는 일음절들을 난수표를 이용한 무선 조합을 실시

Table 1. Participants' characteristics in the SSD and TD groups

\begin{tabular}{|c|c|c|c|c|}
\hline & \multicolumn{2}{|c|}{ SSD group $(\mathrm{N}=20)$} & \multicolumn{2}{|c|}{ TD group $(\mathrm{N}=20)$} \\
\hline & 5 years & 6 years & 5 years & 6 years \\
\hline Number of participants & 10 & 10 & 10 & 10 \\
\hline Gender (male:female) & $6: 4$ & $7: 3$ & $6: 4$ & $4: 6$ \\
\hline Chronological age (mo) & $64.80(7.25)$ & $76.85(6.31)$ & $65.97(6.26)$ & $77.89(5.37)$ \\
\hline \multicolumn{5}{|l|}{$\mathrm{REVT}^{\mathrm{a}}$} \\
\hline Receptive vocabulary age (mo) & $59.70(2.94)$ & $71.60(10.52)$ & $60.10(4.48)$ & $72.80(1.39)$ \\
\hline Expressive vocabulary age (mo) & $65.30(5.20)$ & $76.90(3.47)$ & $67.30(2.11)$ & $75.00(4.49)$ \\
\hline \multicolumn{5}{|l|}{ U-TAP } \\
\hline $\operatorname{PCC}(\%)$ & $87.40(2.71)$ & $90.30(3.49)$ & $98.90(1.19)$ & $99.3(1.25)$ \\
\hline
\end{tabular}

Values are presented as mean (SD).

$\mathrm{SSD}=$ children with speech sound disorder; $\mathrm{TD}=$ children with typically developing; $\mathrm{PCC}=$ percentage of consonants correct; REVT=Receptive \& Expressive Vocabulary Test (Kim, Hong, Kim, Jang, \& Lee, 2009); U-TAP= Urimal Test of Articulation and Phonology (Kim \& Shin, 2004). 
하여 제작한 것으로, 단어유사성이 낮은 음소조합들이다. 모음은

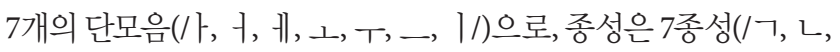
ᄃ, ㄹ, ㅁ, ㅂ, 이)으로 구성되었고, 조음능력의 미성숙으로 인한 과제수행의 어려움을 최대한 배제하기 위해 초성에 치경마찰음과 파찰음은 제외하였다. 과제는 3 음절, 4 음절, 5 음절 비단어 각 10 개 씩, 총 30 개의 항목으로 이루어져 있다. 과제 시행은 반복하지 않고 한 차례의 기회만 주어지며, 비단어 자극 전체를 정확하게 따라말 하면 1점, 그 이외에는 모두 0 점으로 처리된다. 따라서 모든 항목을 정반응한 경우, 3 음절, 4 음절, 5 음절 과제에서 각각 10 점씩을 받게 된다. 본 연구에서 사용한 비단어 따라말하기 검사 항목을 Appen$\operatorname{dix} 1$ 에 제시하였다.

\section{연구절차}

모든 대상자는 조용하고 독립된 공간에서 연구자와 일대일로 실 험에 참여하였다. 실험 순서는 숫자 바로 따라하기, 숫자 거꾸로 따 라하기, 비단어 따라말하기 순으로 진행되었다. 각 과제 내에서 항 목제시 순서는 숫자 바로 따라하기와 거꾸로 따라하기의 경우 한국 웩슬러아동지능검사와 동일하게, 비단어 따라말하기의 경우 Appendix 1에 제시된 순서와 동일하게 하였다. 검사자는 실험 시작 전 모든 대상자들에게 과제수행 방법을 자세히 설명하였다. "선생님 이 불러주는 숫자를 잘 들은 후 똑같은 순서로(또는 뒤에서부터 앞 으로 거꾸로) 따라하는 거예요" 또는 "선생님이 불러주는 말소리 를 잘 들은 후 똑같이 따라말하는 거예요”라고 방법을 알려주면서, 각 과제 별로 연습문항을 반복 실시하여 충분한 연습기회를 가졌 다. 아동이 실험방법을 충분히 숙지한 것이 확인되면 이후 본 실험 을 시작하였다. 모든 항목은 단 한 차례의 기회만 허용하였으나, 외 부적인 방해 등으로 아동이 자극어를 못 들었을 경우에는 한 차례 더 들려주었다. 아동의 모든 반응은 연구자가 직접 기록하였다.

\section{통계 분석}

자료의 통계처리는 SPSS version 23.0(IBM, Armonk, NY, USA) 을 이용하여 분석하였다. 첫째, 장애여부(말소리장애 vs. 일반) 및
연령 집단(6세 vs. 7세) 간 과제유형(바로 vs. 거꾸로)에 따른 숫자 따 라하기 점수에 차이가 있는지 알아보기 위해, 2피험자 간-1피험자 내 혼합설계에 따른 반복측정분산분석(repeated measures ANO$\mathrm{VA}$ )을 실시하였다. 둘째, 장애여부(말소리장애 vs. 일반) 및 연령 집 단(6세 vs. 7세) 간 음절수(3음절 vs. 4 음절 vs. 5 음절)에 따른 비단 어 따라말하기 점수에 차이가 있는지 알아보기 위해, 2피험자 간-1 피험자 내 혼합설계에 따른 반복측정분산분석을 실시하였다. 이 때 과제유형 및 음절수에 따른 분석 시 Mauchly 구형성 가정을 충 족하지 못한 경우 Greenhouse-Geisser의 수정된 자유도를 이용하 여 결과를 해석하였다. 셋째, 숫자 바로 따라하기, 숫자 거꾸로 따라 하기, 음절수별 비단어 따라말하기 점수와 자음정확도, 수용어휘 량, 표현어휘량 간 상관관계가 있는지 알아보기 위해 Pearson 적률 상관관계 분석을 실시하였다. 장애여부 및 연령 집단별로 상관관계 를 분석할 경우 대상자수가 10 명씩으로 그 수가 너무 적어, 상관관 계 분석은 말소리장애 아동 전체(20명)와 일반아동 전체(20명)에 서 실시하였다.

\section{연구결과}

\section{말소리장애 아동과 일반아동 간 연령별 과제유형에 따른 숫자 따라하기 정반응 점수 비교}

말소리장애 아동과 일반아동의 5 세와 6 세 집단에서 숫자 바로 따라하기와 숫자 거꾸로 따라하기 정반응 점수에 대한 기술통계는 Table 2 와 같다. 두 집단 모두 5세보다 6세의 수행력이 평균적으로 높다는 것을 알 수 있다. 가장 눈에 띄는 점은 말소리장애 아동의 경우 5 세와 6 세 모두 숫자 거꾸로 따라하기에서 거의 점수를 얻지 못해 장애여부에 따른 두 집단 간 차이가 매우 두드러진다는 것이 다. 이상과 같은 차이가 통계적으로 유의한지 알아본 결과, 장애여 부에 따른 집단 간 차이 $\left(F_{(1,36)}=260.467, p<.001\right)$, 연령에 따른 집단 간 차이 $\left(F_{(1,36)}=124.839, p<.001\right)$, 그리고 장애여부와 연령 집단 간 상호작용효과 $\left(F_{(1,36)}=92.450, p<.001\right)$ 가 유의하였다. 또한 집단 내 과제유형에 따른 주효과 $\left(F_{(1,36)}=240.925, p<.001\right)$ 와 장애여부와

Table 2. Descriptive analysis on the scores of digit span (forward and backward) tasks by groups

\begin{tabular}{|c|c|c|c|c|c|c|}
\hline & \multicolumn{3}{|c|}{ SSD group } & \multicolumn{3}{|c|}{ TD group } \\
\hline & 5 years $(N=10)$ & 6 years $(N=10)$ & Total $(N=20)$ & 5 years $(N=10)$ & 6 years $(N=10)$ & Total $(\mathrm{N}=20)$ \\
\hline \multicolumn{7}{|c|}{ Digit span task } \\
\hline Forward & $9.00(1.70)$ & $12.40(1.58)$ & $10.70(2.36)$ & $9.80(1.99)$ & $14.40(1.58)$ & $12.10(2.94)$ \\
\hline Backward & $.40(1.26)$ & .80 (1.69) & $.60(1.47)$ & $7.00(1.70)$ & $14.80(1.40)$ & $10.90(4.28)$ \\
\hline
\end{tabular}

Values are presented as mean (SD).

$\mathrm{SSD}=$ children with speech sound disorder; $\mathrm{TD}=$ children with typically developing. 
과제유형 간 상호작용효과 $\left(F_{(1,36)}=149.453, p<.001\right)$ 가 유의하였고, 장애여부, 연령 및 과제유형 간 삼요인 상호작용효과 $\left(F_{(1,36)}=18.132\right.$, $p<.001)$ 도 유의하였다. 그러나 연령과 과제유형 간 상호작용효과 는 유의하지 않았다 $\left(F_{(1,36)}=.019, p>.05\right)$.

유의한 상호작용효과에 대한 사후검정을 위해 이요인 상호작용 효과는 COMPARE 하위명령어를, 삼요인 상호작용효과는 LMATRIX 하위명령어를 syntax editor에 입력하여 결과를 얻었다. 우선 장애여부와 연령 집단 간 상호작용효과의 분석 결과, 5 세에서도 말 소리장애 집단과 일반 집단 간 차이가 유의하였으나 $(p<.01), 6$ 세의 경우 그 차이가 더욱 두드러진 것으로 확인되었다 $(p<.001)$. 그리고 장애여부와 과제유형 간 상호작용효과를 분석한 결과, 말소리장애 집단은 두 과제 간 차이가 유의하였으나 $(p<.001)$, 일반 집단에서 는 그 차이가 유의하지 않은 것으로 나타났다( $p>.05)$. 마지막으로 장애여부, 연령, 과제유형 간 삼요인 상호작용효과를 분석한 결과, 일반아동의 경우 5 세에서는 두 과제유형 간 차이가 유의하였으나 $(p<.001), 6$ 세가 되면 숫자 거꾸로 따라하기의 수행능력이 향상되 어 두 과제유형 간 유의한 차이가 없어졌다. 반면 말소리장애 아동 은 6 세에도 여전히 숫자 거꾸로 따라하기에 어려움을 보여, 5 세와 6
세 모두에서 과제유형 간 유의한 차이가 관찰되었다 $(p<.001)$ (Figure 1).

\section{말소리장애 아동과 일반아동 간 연령별 음절수에 따른 비단어 따라말하기 정반응 점수 비교}

말소리장애 아동과 일반아동의 5 세와 6 세 집단에서 음절수별 비단어 따라말하기 정반응 점수에 대한 기술통계는 Table 3 과 같 다. 두 집단 모두 모든 음절수에서 5 세보다 6 세의 수행력이 평균적 으로 높았다. 말소리장애 아동의 경우 음절수가 길어질수록 일반 아동에 비해 수행력이 더욱 저하되어, 장애여부에 따른 두 집단 간 차이가 더욱 두드러지는 것을 알 수 있다. 이와 같은 차이가 통계적 으로 유의한지 알아본 결과, 장애여부에 따른 집단 간 차이 $\left(F_{(1,36)}=\right.$ $91.317, p<.001)$ 와 연령에 따른 집단간차이 $\left(F_{(1,36)}=102.158, p<.001\right)$ 가 유의하였으나, 장애여부와 연령 집단간 상호작용효과 $\left(F_{(1,36)}=.034\right.$, $p>.05$ )는 유의하지 않았다. 그리고 집단 내 음절수에 따른 주효과 $\left(F_{(1,36)}=72.851, p<.001\right)$ 와 장애여부와 음 절수 간 상호작용효과 $\left(F_{(1,36)}=30.284, p<.001\right)$ 는 유의하였으나, 연령과 음절수 간 상호작 용효과 $\left(F_{(1,36)}=.372, p>.05\right)$ 와 장애여부, 연령, 음절수 간 삼요인 상

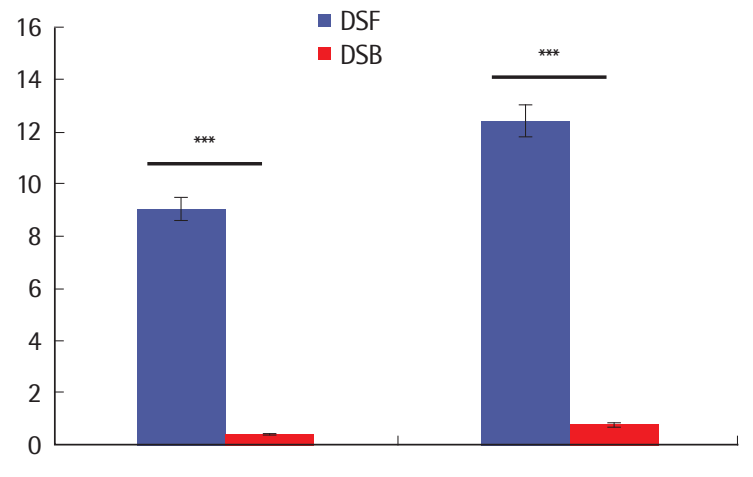

5 years
6 years

SSD

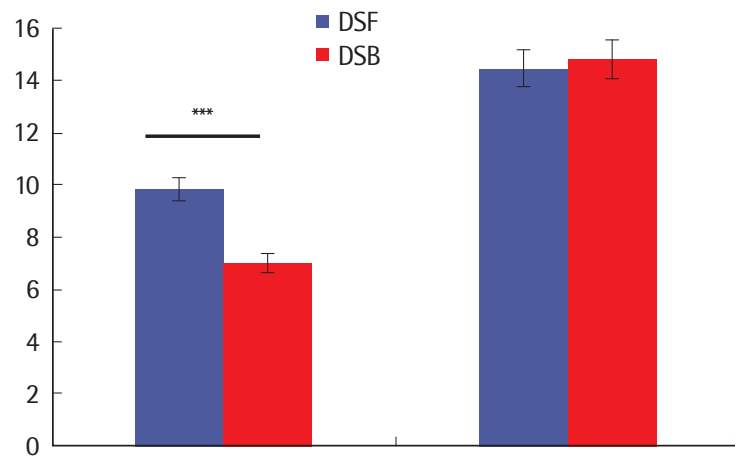

5 years
6 years

TD

Figure 1. Digit span performance according to the task type of 5 and 6 years between two groups. ${ }^{* *} p<.001$.

$\mathrm{SSD}=$ children with speech sound disorder; $\mathrm{TD}$ = children with typically developing; $\mathrm{DSF}=$ digit span forward; $\mathrm{DSB}=$ digit span backward.

Table 3. Descriptive analysis on the scores of nonword repetition tasks by groups

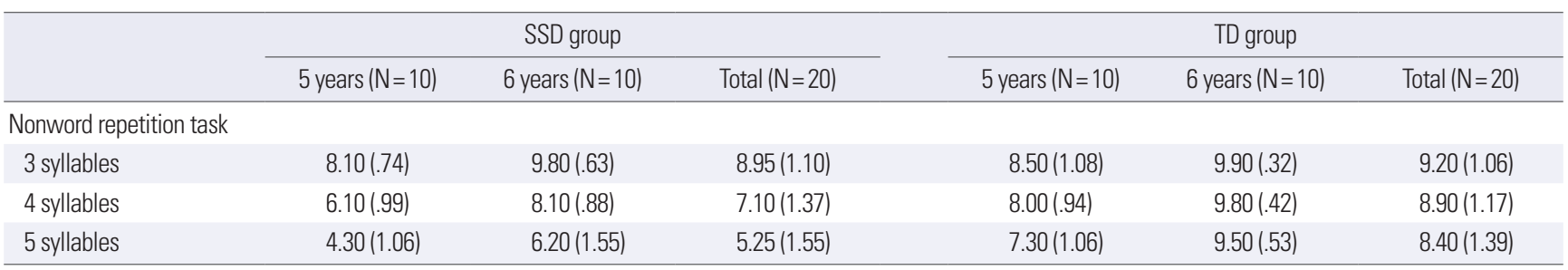

Values are presented as mean (SD).

$S S D=$ children with speech sound disorder; $T D=$ children with typically developing . 


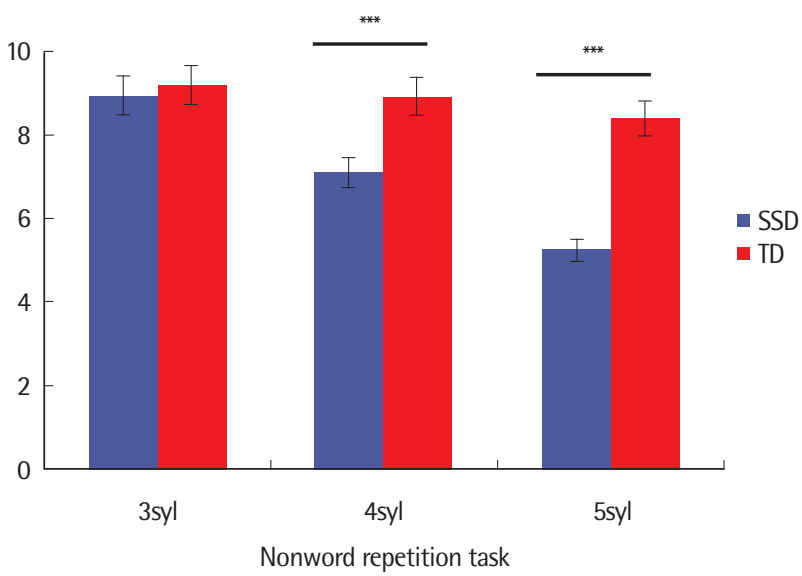

Figure 2. Nonword repetition performance according to number of syllables between two groups. ${ }^{* * *} p<.001$.

$S S D=$ children with speech sound disorder; $T D=$ children with typically developing.
호작용효과 $\left(F_{(1,36)}=.258, p>.05\right)$ 는 유의하지 않았다.

음절수에 따른 주효과에 대해 Bonferroni 사후검정을 실시한 결 과, 3 음절과 4 음절, 3 음절과 5 음절, 4 음절과 5 음절 간, 즉 모든 음절 수 간 차이가 유의하였다 $(p<.001)$. 장애여부와 음절수와 간 상호 작용효과에 대해 COMPARE 하위명령어를 입력하여 사후검정을 실시한 결과, 4 음절과 5 음절 비단어에서는 말소리장애 집단과 일 반 집단 간 차이가 유의하였으나 $(p<.001), 3$ 음절에서는 장애여부 에 따른 집단 간 차이가 유의하지 않은 것이 확인되었다 $(p>.05)$

(Figure 2).

\section{각 과제 수행력과 자음정확도, 수용어휘량, 표현어휘량 간 상관관계}

말소리장애 아동 집단과 일반아동 집단에서 숫자 바로 및 거꾸 로 따라하기 점수, 3 음절, 4 음절, 5 음절 비단어 따라말하기 점수, 그

Table 4. Correlation among task scores, PCC, REVT-R, and REVT-E in SSD group

\begin{tabular}{|c|c|c|c|c|c|c|c|c|}
\hline & DSF & DSB & $\begin{array}{l}\text { NWR } \\
\text { (3syl) }\end{array}$ & $\begin{array}{l}\text { NWR } \\
\text { (4syl) }\end{array}$ & $\begin{array}{l}\text { NWR } \\
\text { (5syl) }\end{array}$ & $\begin{array}{c}\text { PCC } \\
(\text { U-TAP, \%) }\end{array}$ & $\begin{array}{c}\text { REVT-R } \\
\text { (raw score) }\end{array}$ & $\begin{array}{c}\text { REVT-E } \\
\text { (raw score) }\end{array}$ \\
\hline DSF & 1 & & & & & & & \\
\hline DSB & -.128 & 1 & & & & & & \\
\hline NWR (3syl) & $.541^{*}$ & .020 & 1 & & & & & \\
\hline NWR (4syl) & $.529^{*}$ & .073 & $.562^{* *}$ & 1 & & & & \\
\hline NWR (5syl) & .438 & .023 & .378 & $.630^{* *}$ & 1 & & & \\
\hline PCC (U-TAP, \%) & .343 & -.037 & .405 & .331 & .111 & 1 & & \\
\hline REVT-R (raw score) & $.739^{* *}$ & .151 & $.662^{* *}$ & $.739^{* *}$ & $.584^{* *}$ & .408 & 1 & \\
\hline REVT-E (raw score) & $.627^{* *}$ & .190 & $.555^{* *}$ & $.589^{* *}$ & $.603^{* *}$ & .428 & $.880^{* *}$ & 1 \\
\hline
\end{tabular}

$\mathrm{SSD}=$ children with speech sound disorder; $\mathrm{DSF}=$ digit span forward; $\mathrm{DSB}=$ digit span backward; NWR=nonword repetition; $\mathrm{PCC}=$ percentage of consonants correct; $\mathrm{U}-\mathrm{TAP}=$ Urimal Test of Articulation and Phonology (Kim \& Shin, 2004); REVT=Receptive \& Expressive Vocabulary Test (Kim, Hong, Kim, Jang, \& Lee, 2009); REVT-R= receptive score of REVT; REVT-E = expressive score of REVT.

${ }^{*} p<.01,{ }^{* *} p<.01$.

Table 5. Correlation among task scores, PCC, REVT-R, and REVT-E in TD group

\begin{tabular}{|c|c|c|c|c|c|c|c|c|}
\hline & DSF & DSB & $\begin{array}{l}\text { NWR } \\
\text { (3syl) }\end{array}$ & $\begin{array}{l}\text { NWR } \\
\text { (4syl) }\end{array}$ & $\begin{array}{l}\text { NWR } \\
\text { (5syl) }\end{array}$ & $\begin{array}{c}\text { PCC } \\
(\mathrm{U}-\mathrm{TAP}, \%)\end{array}$ & $\begin{array}{c}\text { REVT-R } \\
\text { (raw score) }\end{array}$ & $\begin{array}{c}\text { REVT-E } \\
\text { (raw score) }\end{array}$ \\
\hline DSF & 1 & & & & & & & \\
\hline DSB & $.814^{* *}$ & 1 & & & & & & \\
\hline NWR (3syl) & $.434^{*}$ & $.680^{* *}$ & 1 & & & & & \\
\hline NWR (4syl) & $.618^{* *}$ & $.779^{* *}$ & $.744^{* *}$ & 1 & & & & \\
\hline NWR (5syl) & $.582^{* *}$ & $.767^{* *}$ & $.587^{* *}$ & $.740^{* *}$ & 1 & & & \\
\hline PCC (U-TAP, \%) & -.003 & .144 & -.016 & .119 & .038 & 1 & & \\
\hline REVT-R (raw score) & $.626^{* *}$ & $.589^{* *}$ & .345 & $.461^{*}$ & $.509^{*}$ & -.040 & 1 & \\
\hline REVT-E (raw score) & $.637^{* *}$ & $.625^{* *}$ & .404 & $.513^{*}$ & $.513^{*}$ & .206 & $.893^{* *}$ & 1 \\
\hline
\end{tabular}

$\mathrm{TD}=$ children with typically developing; $\mathrm{DSF}=$ digit span forward; $\mathrm{DSB}=$ digit span backward; NWR= nonword repetition; $\mathrm{PCC}=$ percentage of consonants correct; $\mathrm{U}-\mathrm{TAP}=\mathrm{Urimal}$ Test of Articulation and Phonology (Kim \& Shin, 2004); REVT = Receptive \& Expressive Vocabulary Test (Kim, Hong, Kim, Jang, \& Lee, 2009); REVT-R= receptive score of REVT; REVT-E $=$ expressive score of REVT.

${ }^{*} p<.01,{ }^{* *} p<.01$. 
리고 자음정확도, 수용 및 표현어휘량 간 상관관계는 Tables 4,5 와 같다. 말소리장애 아동의 경우 숫자 바로 따라하기와 숫자 거꾸로 따라하기 간에는 유의한 상관이 없었고( $p>.05)$, 숫자 바로 따라하 기와 3음절, 4 음절의 비단어 따라말하기 간에 상관계수 .541과 .529 의 유의한 정적상관이 있었다 $(p<.05)$. 비단어 따라말하기에서 는 3 음절과 4 음절 간, 4 음절과 5 음절 간 상관계수가 . 562 와 .630으 로, 상관이 유의하게 있거나 높은 편이었다 $(p<.01)$. 반면 일반아동 의 경우 숫자 바로 따라하기와 숫자 거꾸로 따라하기에서 상관계수 .814 의 유의하게 매우 높은 상관을 보였고 $(p<.01)$, 숫자 바로 따라 하기, 숫자 거꾸로 따라하기, $3,4,5$ 음절 비단어 따라말하기 간에도 모두 유의한 정적상관을 보였다 $(p<.05$ 또는 $p<.01)$.

자음정확도, 수용 및 표현어휘력과 실험과제 간 상관관계를 분석 한 결과, 말소리장애 아동과 일반아동 집단 모두 자음정확도와 모든 실험과제 점수 간에는 유의한 상관관계를 보이지 않았다( $p>.05)$. 그러나 수용어휘량과 표현어휘량은, 말소리장애 아동은 숫자 거꾸 로 따라하기를, 일반아동은 3 음절 비단어 따라말하기를 제외하고, 나머지 과제들과 상관이 유의하게 있거나 높은 편이었다 $(p<.05$ 또 는 $p<.01)$.

\section{논의 및 결론}

본 연구에서는 5 세와 6 세의 말소리장애 아동과 일반아동에게 숫자 바로 따라하기, 숫자 거꾸로 따라하기, $3,4,5$ 음절 비단어 따라 말하기 과제를 실시하여, 집단과 연령 간 음운단기기억과 음운작 업기억 능력을 비교하고 두 기억기제와 말소리산출능력, 어휘능력 과의 관련성을 밝히고자 하였다. 연구결과, 숫자 따라하기와 비단 어 따라말하기 과제 모두에서 장애여부와 연령에 따른 집단 간 유 의한 차이를 확인할 수 있었다. 그러나 두 과제 각각에서 과제유형 과 음절수에 따라 말소리장애 집단과 일반 집단의 수행 양상이 달 랐고, 특히 숫자 따라하기의 경우 연령을 변수에 포함하였을 때에 는 또 다른 양상이 관찰되었다. 또한 말소리장애 집단과 일반 집단 간 수용 및 표현어휘량과 유의한 상관관계를 보인 과제의 종류가 서로 다르다는 것도 알 수 있었다. 이와 같은 연구결과에 대해좀 더 심층적인 논의가 필요할 것이다.

우선 숫자 따라하기 과제에서 유의하였던 주효과와 상호작용효 과를 종합적으로 해석해보면 다음과 같이 정리할 수 있다. 5 세와 6 세 모두에서 말소리장애 아동은 과제유형에 상관없이 일반아동보 다 그 수행력이 떨어졌다. 즉, 5 세와 6 세 말소리장애 아동은 동일 연 령대의 일반아동보다 음운단기기억과 음운작업기억 모두에 결함 을 보인다. 그러나 장애여부와 연령 간 유의한 상호작용효과로 인
해, 장애여부에 따른 두 집단 간 차이가 5세보다 6세에서 더욱 두드 러진다는 사실이 확인되었다. 이와 같이 6세에서 집단 간 격차가 크 게 벌어진 이유는 장애여부, 연령, 과제유형 간 삼요인 상호작용효 과 결과를 통해 유추할 수 있다. 일반아동의 경우 숫자 거꾸로 따라 하기는 5 세에서는 어려운 과제이지만 6 세가 되면 그 수행력이 급격 하게 향상되어, 숫자 바로 따라하기와 점수상 차이를 보이지 않았 다. 다시 말해, 일반아동은 5 세에는 아직 서툴렀던 작업기억 능력 이 6세가 되면 눈에 띄게 향상되어 단기기억 과제만큼 수월하게 그 과제를 해낼 수 있다. 반면 말소리장애 아동의 경우 5 세뿐 아니라 6 세에도 숫자 거꾸로 따라하기는 여전히 매우 어려운 과제로, 수행 을 거의 전혀 해내지 못하였다(Table 2). 때문에 작업기억 능력의 격 차로 인해 6세에 이르면 두 집단의 차이가 더욱 두드러졌다. 이 같은 양상은 장애여부와 과제유형 간 상호작용효과에도 반영되어, 연령 에 상관없이 과제유형에 따라 말소리장애 집단은 유의한 차이를 보 이는 반면, 일반 집단은 그렇지 않은 것으로 나타났다.

이상의 결과는 말소리장애 아동은 음운단기기억 또는 작업기억 에 결함을 보인다는 선행연구들(Afshar et al., 2017; Farquharson et al., 2018; Kim \& Ha, 2014)과 다르지 않은 결과이다. 그러나 본 연 구를 통해 말소리장애 아동은 음운작업기억에 특히 더 어려움을 보이며, 일반아동과 달리 6세가 되어도 그 능력이 조금도 향상되지 않았음을 알 수 있었다. 말소리장애 아동의 경우 5 세에서 6세로 연 령이 높아짐에 따라 음운단기기억은 그래도 점차적으로 향상 되지 만 그에 반해 작업기억은 전혀 발달되지 않았다는 본 연구의 결과 는, 지속적 말소리장애가 음운작업기억의 결함으로 초래될 수 있 고(Farquharson et al., 2018) 지속적 말소리장애를 예측할 수 있는 결정적 연령이 5세 6개월 혹은 6세 이후라는 선행연구(Bishop \& Adams, 1990; Shriberg et al., 1997)를 상기시킨다. 즉, 6세에도 여전 이 말소리산출에 문제를 보이는 아동들은 음운작업기억의 결함이 두드러지고, 그러한 음운작업기억 결함은 말소리장애를 지속시키 는 요인과 관련이 있는 듯 하다. 그러나 5 세 말소리장애 아동에게는 이러한 해석이 적절하지 않을 것인데, 그 이유는 일반아동의 경우 에도 음운작업기억 능력을 활발하게 발달시키는 연령이 6세이기 때문이다.

말소리장애 아동이 음운기억에 결함을 보인다는 사실은 본 연구 의 비단어 따라말하기 결과를 통해서도 다시 한 번 확인되었다. 연 구 결과 연령에 상관없이 말소리장애 아동은 일반아동보다 비단어 따라말하기 수행력이 유의하게 떨어졌다. 또한 음절수에 따른 모든 항목 간 차이가 유의하여, 비단어 따라말하기는 음절길이효과를 민감하게 반영하는 과제라는 것도 알 수 있었다. 장애여부와 음절 수 간 유의한 상호작용효과에 대해 사후검정을 실시한 결과, 말소 
리장애 아동과 일반아동 간 수행력 차이는, 3 음절에서는 나타나지 않았고 4 음절과 5 음절에서만 나타났다. 이는 비단어 따라말하기에 대한 여러 선행연구들과 동일한 결과이며(Gathercole \& Baddeley, 1990), 따라서 장애여부에 따른 집단 간 차이를 민감하게 보기 위해 서는 4 음절 이상의 비단어 자극어를 사용하는 것이 타당할 것이다.

비단어 따라말하기가 음운단기기억과 작업기억 중 어디에 해당 하는 과제인지에 대해서는, 본 연구결과 작업기억보다는 단기기억 을 평가하는 과제에 가깝다고 결론을 내릴 수 있다. 그 이유는 숫자 거꾸로 따라하기에서와 같이 장애여부에 따른 집단 간 급격한 수 행 차이가 비단어 따라말하기 과제에서는 관찰되지 않았기 때문이 다. 말소리장애 아동은 음절길이가 길어질수록 일반아동보다 더욱 어려움을 보이기는 했지만, 숫자 거꾸로 따라하기보다는 훨씬 양호 한 반응을 보여주었다. 따라서 비단어 따라말하기는 숫자 거꾸로 따라하기처럼 적극적인 처리와 조작활동이 요구되는 과제는 아닌 것으로 보인다. 단, 이러한 해석은 본 연구에서 사용한 $3,4,5$ 음절 비단어 자극어에만 한정된 것으로, 5 음절보다 음절수가 더 길어질 경우 단기기억 이외에 또 다른 인지기제가 요구될지는 본 연구결과 로는 알수 없다.

각 과제의 수행력 간 상관관계를 살펴본 결과, 말소리장애 집단 과 일반 집단 간 상관 양상은 동일하지 않았다. 가장 두드러지는 차 이점은 숫자 바로 따라하기와 거꾸로 따라하기의 상관으로, 일반 아동은 두 과제유형 간 유의하게 매우 높은 정적상관을 나타낸 반 면 $(r=.814, p<.001)$, 말소리장애 아동은 유의한 상관을 보이지 않 았다 $(r=-.128, p>.05)$ (Tables 4, 5). 이는 말소리장애 집단에서 숫 자 거꾸로 따라하기 과제에 바닥효과(floor effect)가 나타났기 때문 인 것으로 여겨진다. 두 집단 간 숫자 따라하기와 비단어 따라말하 기의 상이한 상관 양상도 이와 유사한 해석이 가능하다. 앞에서 언 급하였듯이 비단어 따라말하기가 단기기억 과제에 해당한다고 전 제할 때, 모든 음절수의 비단어 따라말하기 수행력이 숫자 바로 따 라하기뿐 아니라 거꾸로 따라하기의 수행력과도 유의한 상관이 있 었던 일반아동의 결과는 숫자 따라하기 과제에서 두 과제유형 간 높은 상관을 보여주었던 결과와 같은 맥락에서 해석할 수 있다. 반 면 말소리장애 아동은, 숫자 따라하기에서 두 과제유형 간 유의한 상관이 나타나지 않았던 것처럼 비단어 따라말하기 수행력은 단지 숫자 바로 따라하기와 상관이 있었을 뿐 숫자 거꾸로 따라하기와 는 유의한 상관을 보이지 않았다.

서론에서도 언급하였듯이 음운단기기억은 주어진 정보를 단지 수동적으로 보유하는 것이고, 음운작업기억은 적극적인 처리와 조 작을 통해 그 정보를 좀 더 오랫동안 유지하고 기억하려는 노력이 다. 따라서 작업기억은 단기기억을 발판으로 하지만 성공적 처리와
조작을 위해 그 이상이 필요하다. 그 예로 자극정보에 대해 효율적 으로 주의를 통제할 수 있는 집행주의(executive attention), 그리고 일련의 말소리 정보들을 민감하고 정확하게 인지하는 음운인식능 력 등을 생각해볼 수 있다. 말소리장애 아동은 주의력 결함을 동반 하고(Joo \& Ha, 2018), 음운인식에 어려움을 보인다(Seo, Ko, Oh, \& $\mathrm{Kim}, 2017)$ 는 선행연구들을 고려할 때, 음운단기기억, 주의력, 음 운인식 모두에 결함을 보이는 말소리장애 아동의 경우 그 결함들 이 복합적으로 작용하여 음운작업기억 과제의 수행에 이처럼 큰 어려움을 보일 가능성을 생각해볼 수 있다.

그러나 그보다 더욱 근본적으로 '말소리장애'라는 이 아동들이 가진 특성과 그와 관련하여 시연활동의 부재 또는 어려움에서 그 해답을 찾을 수 있을 듯하다. Baddeley의 모델에 의하면 작업기억 은 단기기억 저장소와 시연과정을 통해 이루어진다(Baddeley \& Hitch, 1974). 그러나 Baddeley의 작업기억 모델은 일반아동에게만 적용되는 과정으로 여겨진다. 일반아동은 5 세와 6 세를 거치며 점 차적으로 단기기억을 완성시켜 갔으며, 6세 이후에는 작업기억능 력 또한 급격하게 발달시켜 단기기억만큼 작업기억 과제에도 어려 움이 없었다. 5 세 경에는 기본적인 단기기억능력이 갖춰지고, 이후 능숙한 음운처리 및 음운산출능력이 가능해지면서 내연적(subvo$\mathrm{cal}$ ) 혹은 외연적(vocal) 시연활동을 통해 작업기억능력을 갖추어 갈 것이다. 그러나 말소리장애 아동의 경우 6세에 이르면 단기기억 능력은, 물론 일반아동보다는 여전히 부족하지만, 그래도 어느 정 도 갖추었으나 작업기억활동은 전혀 나타나지 않았다. 시연활동은 말소리를 반복적으로 되뇌는 것으로 이는 분명 능숙한 음운처리 및 음운산출능력을 전제한다. 따라서 말소리장애 아동이 가진 음 운능력의 결함은 곧 시연활동의 어려움으로 연결되고, 이는 결과 적으로 작업기억활동의 부재를 초래할 가능성이 있다. 이와 관련 하여 Kim (2017)의 연구에서는 말소리장애 아동은 음운정보를 오 랫동안 기억하는 데에 일반아동만큼 시연활동을 통해 이득을 얻 지 못한다고 보고된 바 있다.

작업기억능력의 결함은 언어발달과 밀접한 관련이 있다(Archibald, 2017; Baddeley, 2003). 따라서 본 연구에서도 각 과제의 수행 력과 자음정확도, 수용어휘량, 표현어휘량과의 상관관계를 분석해 보았다. 그 결과 말소리장애와 일반아동 모두에서 자음정확도는 단기기억 및 작업기억 수행력과 아무런 상관이 없었다. 이러한 결 과는 음운처리적 측면까지 아우르기에 자음정확도는 그 측정과 분 석방법상 제한점이 있는 지표일 수 있음을 시사한다. 따라서 음운 기억과 말소리능력 간 관계를 살펴보기 위해서는 자음정확도 외에 다른 음운지표를 활용하는 것이 보다 적절할 것으로 보이며, 이에 대해서는 추후 연구에서 구체적으로 살펴볼 필요가 있을 것이다. 
음운작업기억은 언어발달 가운데에서도 특히 어휘습득과 관련 성이 큰 것으로 알려져 있다(Baddeley, 2003). 본 연구에서도 수용 어휘량 및 표현어휘량은 실험 과제의 수행력과 유의한 상관관계가 있는 것으로 관찰되었다. 그러나 두 집단 간 그 양상이 다르게 나타 났는데, 말소리장애 집단에서는 숫자 바로 따라하기와 모든 음절수 의 비단어 따라말하기와, 일반 집단에서는 숫자 바로 따라하기, 숫 자 거꾸로 따라하기, 그리고 4 음절과 5음절의 비단어 따라말하기 와 유의한 상관이 있었다. 주목할 점은 일반아동의 경우 수용 및 표 현어휘량은 단기기억 과제뿐 아니라 작업기억 과제와도 관련성이 있었으나, 말소리장애 아동은 단지 단기기억 과제와만 상관관계가 나타났다는 것이다. 이 또한 말소리장애 집단에서 나타난 숫자 거 꾸로 따라하기 과제의 바닥효과로 인한 결과로 보인다. 능숙하게 어 휘를 습득해 나가기 위해서는 의미와 연결된 소리정보들을 잘 보유 하고 되뇌여 효과적으로 기억 속에 저장해야 할 것이다. 수용, 표현 어휘량과 단기기억, 작업기억의 유의한 상관관계에 근거할 때, 일반 아동은 이러한 과정을 거쳐 효율적으로 어휘를 습득해 나가는 듯 하다. 그러나 말소리장애 집단의 경우 작업기억의 결함, 그로 인한 작업기억과 어휘능력 간 상관관계의 부재라는 본 연구결과는, 말소 리장애 아동은 작업기억기제를 활용하지 못하고 오직 단기기억에 만 의존하여 비효율적으로 어휘를 습득해나갈 가능성을 시사한다.

그러나 간과하지 말아야 할 점은 본 연구의 대상자들은 모두 언 어능력이 정상 범주에 속하는 순수 말소리장애 아동들이었다는 것이다. 이에 대해 다음의 두 가지 가능성을 생각해볼 수 있다. 첫 째, 말소리장애 아동은 작업기억활동 이외에 또 다른 인지기제 또 는 전략을 활용하여 어휘를 습득해 나갈 가능성이 있다. 전반적인 인지능력이 정상으로 보고된 아동들인 만큼 본인의 약점을 보상할 수 있는 다른 인지기제를 십분 활용할 가능성을 배제할 수 없다. 이 럴 경우 말소리장애 아동의 어휘습득 과정은 일반아동과 질적으 로 다른 것으로 보이며, 이 가능성을 확인하기 위해서는 아동의 어 휘습득 전략에 대한 여러 이론들에 근거하여 추후 보다 심층적인 연구가 이루어져야 할 것이다. 둘째 자음정확도가 아동들의 음운 처리능력을 반영해주지 못하듯이, 수용어휘량과 표현어휘량의 측 정이 말소리장애 아동의 어휘처리 및 어휘인출능력을 대변해주지 못할 가능성에 대해서도 생각해볼 수 있다. 본 연구에서 사용한 수 용·표현어휘력검사(Kim et al., 2009)는 다소 정적인 평가과제에 속 한다. 수용어휘 평가 시 보기항목의 어휘들은 목표어휘를 방해하 는 요소가 거의 없고, 표현어휘 평가 시에는 목표어휘의 산출과정 에 주저, 수정 등의 동반을 허용하고 최종적으로 목표어휘를 산출 하기만 하면 모두 정반응으로 간주한다. 그러나 수용어휘 평가 시 보기항목에 의미적 또는 음운적으로 혼란을 주는 방해어휘가 포
함될 경우 목표어휘 선택에 어려움을 보였다는 연구(Ahn, 2016), 표현어휘 평가 시 자극그림을 보자마자 산출한 첫 반응만을 점수 화하였을 때 어휘인출능력이 떨어졌다는 연구(Kim \& Ha, 2018) 등 말소리장애 아동의 어휘처리 또는 어휘인출능력의 취약함을 보 고한 선행연구들을 찾아볼 수 있다. 따라서 정적 지식보다 동적 처 리능력 평가에 초점을 둔 과제를 실시하였을 때 말소리장애 아동 의 어휘 결함이 비로소 드러날 가능성에 대해서도 앞으로 연구해 볼 필요가 있다.

본 연구는 지속적 말소리장애의 결정적 예측 연령인 5 세와 6 세 아동들을 대상으로 음운단기기억과 음운작업기억력을 구분하여 비교하고, 두 기억기제와 어휘능력과의 관련성을 심층적으로 분석 하였다는 데에 의의가 있다. 그러나 실험방법상 다소 아쉬운 점이 있다는 것 또한 부정할 수 없는데, 대상자 수가 많지 않았던 점, 실 험 자극어를 육성으로 들려준 점, 자극어 제시 회수를 엄격하게 제 한하지 못한 점 등이 그것이다. 무엇보다 앞에서 언급하였던 여러 가능성, 추후 연구의 필요성 등 이제부터 해결해나가야 할 과제들 을 많이 남겨준 연구이기도 하다. 이와 같은 여러 가능성들이 보다 설득력을 얻기 위해서는 앞으로 보다 심층적인 연구를 지속적으로 추진해야 할 것이며, 본 연구는 그러한 후속연구들에 의미 있는 근 거자료로 사용될 수 있을 것으로 기대한다.

\section{REFERENCES}

Afshar, M. R., Ghorbani, A., Rashedi, V., Jalilevand, N., \& Kamali, M. (2017). Working memory span in Persian-speaking children with speech sound disorders and normal speech development. International Journal of Pediatric Otorhinolaryngology, 101, 117-122.

Ahn, J. A. (2016). Performances of receptance based lexical selection test (LST) in preschoolers with and without speech sound disorders (Master's thesis). Daegu University, Gyeongsan, Korea.

Archibald, L. M. D., \& Gathercole, S. E. (2006). Short-term and working memory in specific language impairment. International Journal of Language \& Communication Disorders, 41, 675-693.

Archibald, L. M. M. (2017). Working memory and language learning: a review. Child Language Teaching and Therapy, 33, 5-17.

Baddeley, A. D. (2003). Working memory and language: an overview. Journal of Communication Disorders, 36, 189-208.

Baddeley, A. D., \& Hitch, G. J. (1974). Working memory. In G. A. Bower (Ed.), Recent advances in learning and motivation (pp. 47-90). New York, NY: Academic Press. 
Bae, S. R., Ha, J. W., Koo, M. M., Hwang, Y. M., \& Pyun, S. B. (2016). New phonological representation of children with speech sound disorders. Communication Sciences \& Disorders, 21, 24-36.

Bishop, D. V., \& Adams, C. (1990). A prospective study of the relationship between specific language impairment, phonological disorders and reading retardation. Journal of Child Psychology and Psychiatry, 31, 1027-1050.

Farquharson, K., Hogan, T. P., \& Bernthal, J. E. (2018). Working memory in school-age children with and without a persistent speech sound disorder. International Journal of Speech-Language Pathology, 20, 422-433.

Gathercole, S. E., \& Baddeley, A. D. (1990). Phonological memory deficits in language disordered children: Is there a causal connection? Journal of Memory and Language, 29, 336-360.

Joo, M. J., \& Ha, J. W. (2018). Visual and auditory sustained attention in children with speech sound disorders with and without comorbid language disorders. Communication Sciences \& Disorders, 23, 279-287.

Jung, I. K., Choi, S. Y., \& Ha, J. W. (2015). Internal awareness of phonological representation in children with speech sound disorders. Communication Sciences \& Disorders, 20, 48-59.

Kim, M. J. (2017). Nonword repetition ability according to auditory input enhancement and vocal rehearsal in children with and without speech sound disorder (Master's thesis). Daegu University, Gyeongsan, Korea.

Kim, N. Y., \& Ha, J. W. (2014). Phonological representations in children with articulation and phonological disorders. Communication Sciences \& Disorders, 19, 226-237.

Kim, N. Y., \& Ha, J. W. (2018). Lexical retrieval performance depending on word frequency and phonetic complexity in children with and without speech sound disorders. Proceedings of 2018 Congress of the Korean Academy of Speech-Language Pathology and Audiology, Gwangju, Korea.

Kim, Y. T., Hong, G. H., Kim, K. H., Jang, H. S., \& Lee, J. Y. (2009). Receptive \& expressive vocabulary test (REVT). Seoul: Seoul Community Rehabilitation Center.

Kim, Y. T., \& Shin, M. J. (2004). Urimal test of articulation and phonology.
Seoul: Hakjisa.

Kwak, K. C., Oh, S. W., \& Kim, C. T. (2011). Korean-Wechsler Intelligence Scale for Children-IV (K-WISC-IV). Seoul: Hakjisa.

Lee, S. J., Ha, J. W., Koo, M. M., Hwang, Y. M., \& Pyun, S. B. (2016). Delayed non-word repetition according to rehearsal conditions in 6-to 7-year-old children. Communication Sciences \& Disorders, 21, 69-83.

Newbury, D. F., Bishop, D. V., \& Monaco, A. P. (2005). Genetic influences on language impairment and phonological short-term memory. Trends in Cognitive Sciences, 9, 528-534.

Seo, E. Y., Ko, Y. K., Oh, G. A., \& Kim, S. J. (2017). Phonological Awareness and Vocabulary Characteristics of Children with Speech Sound Disorders. Communication Sciences \& Disorders, 22, 318-327.

Shriberg, L. D., Austin, D., Lewis, B. A., McSweeny, J. L., \& Wilson, D. L. (1997). The speech disorders classification system (SDCS): extensions and lifespan reference data. Journal of Speech, Language, and Hearing Research, 40, 723-740.

Sung, J. E. (2011). The reliability and validity of short-term and working memory pointing tasks developed for clinical populations with speech and language disorders. Korean Journal of Communication \& Disorders, 16, 185201.

Sutherland, D., \& Gillon, G. T. (2005). Assessment of phonological representations in children with speech impairment. Language, Speech, and Hearing Services in Schools, 36, 294-307.

Sutherland, D., \& Gillon, G. T. (2007). Development of phonological representations and phonological awareness in children with speech impairment. International Journal of Language \& Communication Disorders, 42, 229-250.

Tkach, J. A., Chen, X., Freebairn, L. A., Schmithorst, V. J., Holland, S. K., \& Lewis, B. A. (2011). Neural correlates of phonological processing in speech sound disorder: a functional magnetic resonance imaging study. Brain and Language, 119, 42-49. 
Appendix 1. The item list of the nonword repetition task

\begin{tabular}{ccc}
\hline & 비단어 항목 & \\
\hline 3음절 비단어 & 4음절 비단어 & 5음절 비단어 \\
\hline 너눙닉 & 거그툰닌 & 너멜렘두넥 \\
느롱엘 & 버딤네둡 & 버님머넨덱 \\
데릅뜹 & 더렝겡멘 & 뽀넘므텍뜹 \\
느람블 & 꾸머큰넥 & 드메너쁜눔 \\
니버껑 & 뜨네벤닐 & 두레뻬뚤뎁 \\
더눌렁 & 뻬응믄돔 & 그렝뎀꾸겝 \\
드넨넵 & 니덩멜렙 & 느렌두멀릅 \\
머겜밍 & 두넘몽뎅 & 뻬드믈레넴 \\
흐넬맏 & 뿌른번눕 & 삐딩두밍닐 \\
\hline
\end{tabular}




\section{국문초록}

\section{5세와 6세 말소리장애 아동의 음운단기기억과 음운작업기억 능력}

이기은,2 - 하지완 ${ }^{13}$

'대구대학교 재활과학대학원 언어치료학과, ${ }^{2}$ 굿마인드 언어발달센터, ${ }^{3}$ 대구대학교 언어치료학과

배경 및 목적: 5 세와 6 세의 말소리장애 아동과 일반아동 간 음운단기기억과 음운작업기억 능력을 비교 분석하여, 두 기억기제와 말소 리산출능력, 어휘능력과의 관련성을 밝히고자 하였다. 방법: 연구대상은 5 세와 6 세 순수 말소리장애 아동 20 명과 일반아동 20 명이었 다. 음운단기기억 및 음운작업기억 평가를 위해, 숫자 바로 따라하기, 숫자 거꾸로 따라하기, 비단어 따라말하기 과제를 실시하였다. 말 소리산출능력, 어휘능력과의 상관관계 분석을 위해서는 자음정확도, 수용어휘량 및 표현어휘량 지표를 사용하였다. 결과: 숫자 따라하 기와 비단어 따라말하기 과제 모두에서 장애여부와 연령에 따른 집단 간 유의한 차이가 있었다. 일반아동은 5 세에서 숫자 바로 따라하 기와 거꾸로 따라하기 수행력에 유의한 차이를 보였으나, 6 세가 되면 숫자 거꾸로 따라하기의 수행력이 급격히 향상되어 두 과제유형 간 유의한 차이가 없어졌다. 반면 말소리장애 아동은 6 세에도 여전히 숫자 거꾸로 따라하기에 어려움을 보여, 5 세와 6 세 모두에서 두 과제 에 유의한 차이를 보였다. 두 집단 모두에서 각 기억과제의 수행력과 자음정확도는 상관이 없었으나, 수용 및 표현어휘량과는 유의한 상 관을 보였다. 그러나 유의한 상관이 나타난 과제의 종류는 두 집단이 동일하지 않았다. 논의 및 결론: 본 연구는 지속적 말소리장애의 결정적 예측 연령인 5 세와 6 세 아동들을 대상으로 음운단기기억과 음운작업기억력을 구분하여 비교하고, 두 기억기제와 어휘능력과 의 관련성을 심층적으로 분석하였다는 데에 의의가 있다.

핵심어: 순수 말소리장애, 음운단기기억, 음운작업기억. 숫자폭 과제, 비단어 따라말하기 과제

본 연구는 2016학년도 대구대학교 학술연구비 지원에 의하여 연구되었음(No. 20160416).

\section{참고문헌}

곽금주, 오상우, 김청택(2011). 한국판 웩슬러 아동용 지능검사4판(K-WISC-IV). 서울: 학지사.

김나연, 하지완(2014). 조음음운장애아동과 일반아동의 음운표상의 질과 음운표상 부호화 능력 비교. 언어청각장애연구, 19, 226-237.

김나연, 하지완(2018). 말소리장애 아동과 일반 아동 간 단어빈도 및 조음복잡성에 따른 어휘인출 능력 비교. 한국언어청각임상학회 학술대회 자료집. 김미진(2017). 외현적 시연과 청각적 입력 강화가 말소리장애 아동과 일반 아동의 비단어 따라말하기 수행력에 미치는 영향. 대구대학교 대학원 석사 학위논문.

김영태, 신문자 (2004). 우리말 조음·음운평가(U-TAP). 서울: 학지사.

김영태, 홍경훈, 김경희, 장혜성, 이주연(2009). 수용·표현 어휘력 검사(REVT). 서울: 서울장애인종합복지관.

배세령, 하지완, 구민모, 황유미, 편성범(2016). 말소리장애아동의 새로운 음운표상 형성 능력. 언어청각장애연구, 21, 24-36.

서은영, 고유경, 오경아, 김수진(2017). 말소리장애 아동의 음운인식과 어휘 특성. 언어청각장애연구, 22, 318-327.

성지은(2011). 말언어장애군의 단기기억 및 작업기억용량 측정을 위한 지시하기과제 개발 예비연구: 재검사 신뢰도 및 타당도. 언어청각장애연구, 16 ,

185-201.

안진아(2016). 학령전기 일반 아동과 말소리장애 아동의 수용기반 어휘선택과제 수행력. 대구대학교 대학원 석사학위논문.

이석정, 하지완, 구민모, 황유미, 편성범(2016). 6, 7세 아동의 시연조건에 따른 지연 비단어따라말하기 능력 비교. 언어청각장애연구, 21, 69-83.

정일권, 최선영, 하지완(2015). 조음음운장애아동과 일반아동의 음운표상 내적 인식능력 비교. 언어청각장애연구, 20, 48-59.

주미진, 하지완(2018). 순수 말소리장애 아동과 언어장애 동반 말소리장애 아동의 시각 및 청각 지속주의 특성. 언어청각장애연구, 23, 279-287. 